\title{
Okul Öncesi Öğretmen Adaylarının Değerler Eğitimine Yönelik Görüşleri
}

\section{Pre-school Teacher Candidates' Views on Values Education}

Hatice Kübra AKITÜRK, Yüksek Lisans Öğrencisi.

Bursa Uludağ Üniversitesi, Eğitim Bilimleri Enstitüsü.

E-mail: laledansi@gmail.com.

ORCID: 0000-0001-61 15-3543

Pınar BAĞĢELİ KAHRAMAN, Sorumlu Yazar, Dr. Öğr. Üyesi. Bursa Uludağ Üniversitesi, Eğitim Fakültesi.

E-mail: pinarbag@uludag.edu.tr.

ORCID: 0000-0002-0551-7741

ISSN: 1303-880X e-ISSN: 2667-7504 http://ded.dem.org.tr

Geliş/Received: 12.05 .2019 Kabul/Accepted: 06.10 .2019 Makale Yayın: 25.12.2019 Makale Türü/Article Type: Araştırma/Research
Atıf/Citation:Akıtürk, H.K. \& Bağçeli Kahraman, P. (2019). Okul öncesi öğretmen adaylarının değerler eğitimine yönelik görüşleri. Değerler Eğitimi Dergisi,17 (38), 267-294. DOI: $10.34234 /$ ded.563493 
Öz: Bu araştırmanın amacı okul öncesi öğretmen adaylarının değerler eğitimine yönelik görüşlerini belirlemektir. Araştırmanın örneklemini 2018-2019 eğitim öğretim yılında Eğitim Fakültesi Okul Öncesi Eğitimi Anabilim Dalında öğrenim görmekte olan üçüncü ve dördüncü sınıfta öğrenim görmekte olan 116 öğretmen adayı oluşturmaktadır. Bu öğrenciler ölçüt örnekleme yoluyla belirlenmiştir. Araştırma verileri Kişisel Bilgi Formu, sekiz açık uçlu sorudan oluşan Değerler Eğitimine Yönelik Görüş Formu kullanılarak elde edilmiştir. $\mathrm{Bu}$ araştırma nicel araştırma modellerinden tarama modelinde gerçekleştirilmiştir. Araştırma kapsamında görüş formundan elde edilen veriler frekans analizi yoluyla analiz edilmiştir. $\mathrm{Bu}$ araştırma sonucunda değerler eğitimi denildiğinde okul öncesi öğretmen adaylarının akıllarına ilk olarak sevgi, saygı, hoşgörü ve dürüstlük değerleri gelmektedir. Bu değerlerin öğretiminde en çok kullanılabilecek yolların sırasıyla yaratıcı drama, oyun ve Türkçe etkinlikleri olduğu ortaya çıkmaktadır. Öğretmen adaylarının hayatlarında ön planda tuttukları değerler ise saygı, sevgi, hoşgörü ve dürüstlüktür. Ayrıca öğretmen adayları, okul öncesi dönem kişilik gelişiminin en önemli yaş aralığı olduğu için, çocuğun topluma uyumunu sağlaması, onun nasıl bir insan olunacağını belirlemesi ve topluma yararlı ve sağlıklı bireyler olarak yetişmesinde okul öncesinde değerler eğitiminin önemli olduğunu ifade etmişlerdir.

Anahtar Kelimeler: Değerler eğitimi, Okul öncesi, Öğretmen adayı.

$\&$

Abstract: The aim of this study was to determine pre-school teacher candidates' views on values education. The sample of the study consisted of 116 students who were studying in Faculty of Education Preschool Education Department in the 2018-2019 academic year. The selection of students was determined by criterion sampling. The research data was obtained using the Personal Information Form, an open-ended questionnaire consisting of eight open-ended questions. The data obtained from the survey was analyzed by frequency analysis. As a result of the study, values such as; love, respect, tolerance and honesty were found to be among the first that comes to the minds of pre-school teacher candidates. The most common ways of teaching these values were creative drama, game and Turkish course activities respectively. The values that the preschool teacher candidates care most were respect, love, tolerance and honesty in their lives. At the same time, it was seen that the values that first come to the prospective teachers' mind are the ones that coincide with the values they place importance in their lives. In addition, teacher candidates stated that values 
education is important in pre-school education, because pre-school period is the most important age range for personality development, that ensures child adaptation to the society, values determine how to be a human and to raise people who are beneficial and healthy to society.

Keywords: Values education, Preschool, Pre-service teachers.

\section{Giriş}

Değerler, inanç ve tutumlar iç içe görülse de inanç ve tutumdan daha kapsamlıdırlar (Demircioğlu ve Tokdemir, 2008). Değer, bir varlığa, nesneye ya da faaliyete, bireysel ve toplumsal yönden tanınan önem ya da üstünlük olarak tanımlanmaktadır (Aydın, 2010). Güneş'e (2016) göre değerler, toplumsal yaşamın temelini oluşturarak sosyal barış ve ilerlemeye katkı sağlayan, diğer bireylerle fikir iletişimi sağlayarak birlikte yaşamayı sağlayan bir işleve sahiptir. Bu açıdan bakıldığında, milli kültür, öğretmen, aile ve diğer çevre değerlerin kaynağını oluşturan etmenlerdir (Bozdaş, 2013). Kurtulmuş, Tösten ve Gündaş'a (2014) göre ise değerler en genel anlamda bireylerin ya da toplumların kendilerine özgü eylemlerine yön vericidir. Bu sebeple değerleri evrensel olarak anlamak ve değerlerin başkaları tarafından nasıl anlaşıldığını bilmek de önemlidir (Ülavere ve Veisson, 2017).

Değerler Eğitiminin amacı da bireyleri ahlâkî değerlere sahip karakterli, sorumluluk duygusu kazanmış kişiler olarak yetiştirmektir. Bu sebeple bireylere sevgi, sayg1, cesaret, sorumluluk, inanç, azim, erdem, adalet gibi değerler, değerler eğitimi ile kazandırılmaya çalışılmaktadır (Altan, 2011; Kulaksızoğlu ve Dilmaç 2000). Okula başlamadan önce değerlerin öğretilmesinden aile sorumlu olsa da çocuk okula başladıktan sonra değerlerin öğretimi öğretmenlerin görevi olmaktadır (Erikli, 2016). Bu nedenle okulun görevi programda yer alan veya almayan değerleri çocuklara öğretmek ve belirli kurallar çerçevesinde ahlaki gelişimlerine olumlu yönde destek vermektir (Akbaş, 2008).

Okul öncesi eğitim, değerlerin öğretilmesinde önemli yer tutmaktadır (Aydın, 2010). Okul öncesi dönemde çocukların tutum ve davranışlarını yönlendirerek gelişimlerine destek verebilmek, değerlerin öğretimi yoluyla gerçekleştirilmektedir (Öztürk Samur, 2011). Bu sebeple çocukların bireysel ve toplumsal yaşamlarına 1şık tutan değerlerin bu dönemde öğretilmesi bir başlangıç olarak düşünülmektedir (Neslitürk, 2013). Ülavere ve Veisson (2017), dürüstlük, sağlık, yardımseverlik, işbirliği yeteneği, güven, hoşgörü, görev duygusu, bağım- 
sızlık, yaratıcılık ve sorumluluk değerlerinin evrensel değerler olduğunu ve bu değerlerin temelinin okul öncesi dönemde kazandırılmaya başlanması gerektiğini ifade etmektedir. Okul Öncesi Eğitim Programı kapsamında uygulamaya alınan değerler ise; sevgi, saygı, hoşgörü, özgüven, yardımlaşma, işbirliği, iyilik, barış, sorumluluk, dayanışma, paylaşmadır ( MEB, 2013).

Okullarda değerler eğitiminin verilebilmesi için önemli payları olan öğretmenlerin bu süreçte tüm öğeleri incelemesi büyük önem taşımaktadır (Kolaç ve Karadağ 2011; Kurtulmuş, Tösten ve Gündaş, 2014). Bu amaçla öğretmenler sınıflarındaki çocukların kişilik özelliklerini iyi bilmeli, onları çok iyi tanımalı ve hangi değerleri kazanabildiklerini gözlemlemelidir. Öğretmenin bir değeri çocuğa verebilmesi için öncelikle bu değeri içselleştirmesi gerekmektedir. Yani güveni öğretmek isteyen bir öğretmen öncelikle güvenmeli, sevgiyi öğretmek isteyen bir öğretmen ise öncelikle sevmelidir (Kasapoğlu, 2013). Öğretmen saygıll, sevgi dolu, ayrım yapmayan, önemseyen, ilgi gösteren güzel ve yararlı davranışlarıyla örnek bir kişi olmalıdır (Meydan, 2012). Ayrıca, ebeveynler ve öğretmenler çocuklara öğretilecek değerler konusunda hemfikir oldukları zaman bu değerlerin öğretilebileceğine inanmaktadırlar (Cottom, 1996).

Yapılan çalışmalar incelendiğinde; sınıf ve şube öğretmenlerinin değerler ve değerler eğitimine yönelik görüş ve uygulamalarını inceleyen araştırmalara rastlanmıştır (Bozdaş, 2013; Meydan, 2012; Revell ve Arthur, 2007; Thornberg, 2008; Veugelers ve Kat, 2003; Xiaoman, 2006; Whitney, 1986). Tarkoçin, Berktaş ve Uyanık Balat (2013), okul öncesi öğretmenlerinin sınıf içi etkinliklerinde kullandıkları evrensel değerleri incelemişler ve en çok kullanılan değerlerin "sayg1, sorumluluk, nezaket, sabır ve yardımlaşma olduğunu belirlemişlerdir. Thornber ve Oğuz (2013), çalışmalarında öğretmenlerin değerler eğitimi konusundaki bakış açılarını incelemiş ve öğretmenlerin değerleri ve değerler eğitimini tanımladıklarında günlük bir dil kullandıklarını ve bu alanda mesleki bilgi eksiklikleri olduğunu belirlemişlerdir. Kuzu (2015) ise, üniversitede değerler ile ilgili eğitim almayan okul öncesi öğretmenlerinin değerler eğitimi ile ilgili düşüncelerini ve öğretmen görüşlerinin sınıf içi uygulamalara yansımasını incelediği araştırmasında, okul öncesi öğretmenlerin daha çok "İyilikseverlik" ve "Evrensellik" kategorilerindeki değerleri öğretmeyi istediği, bu kategorideki değerleri öğretirken zorlandıkları ve yine öğrencilerde en çok bu iki kategorideki değerlerin geliştiğini düşündükleri sonucuna ulaşmıştır. Yuvacı (2013) da benzer olarak, öğretmenlerin öğrencilere değer eğitimi verirken evrensel değerler vermeyi hedeflediklerini belirlemiştir. Bakan (2018) okul öncesi dönem 
çocuklarına yönelik olarak geliştirdiği Okul Öncesi Değerler Eğitim Programının çocuklarda arkadaşlık, iş birliği, saygı, paylaşma, sorumluluk ve dürüstlük değerlerini olumlu yönde etkilediğini belirlemiştir. Yapılan araştırmalar da değerler eğitiminin uygulandığı programlarda yetişen ve evrensel değerleri benimseyen kişilerin sorumluluklarının bilincinde ve akademik olarak başarılı olduklarını göstermektedir (Costanzo, 2005; Dilmaç, 2007; Ekşi, 2003; Grimbilas, 2009; Katılmış, Ekşi ve Öztürk, 2011; Witherspoon, 2007). Ogelman ve Sarıkaya (2015) okul öncesi öğretmenlerinin genel olarak değerler eğitiminin uygulanması konusunda zorlandıkları durumların olduğunu belirlemişlerdir. Yılmaz ve Yılmaz (2017), sınıf ve okul öncesi öğretmenlerinin değer öğretimi hakkındaki görüşlerini belirlemeye çalıştıkları araştırmada sınıf öğretmenlerinin değer öğretimine ilişkin görüşlerinin okul öncesi öğretmenlerine göre daha olumlu olduğu sonucuna ulaşmışlardır. Genel olarak öğretmen adaylarının da değerlere ve değerler eğitimine ilişkin görüşlerini ortaya koymayı amaçlayan çalışmalara da rastlanmıştır (Aydın ve Sulak, 2015; Dilmaç, Bozgeyikli ve Çık1l1, 2008; Huşu ve Tirri, 2007; Kurtdede, 2009; Oğuz, 2012; Yalmanc1, 2009; Yazar, 2011). Başal, Çelebi ve Malak (2016) okul öncesi öğretmen adaylarının denetim odakları ile insani değerleri arasında bir ilişki olup olmadığını inceledikleri araştırmada, denetim odakları ile insani değerleri arasında anlamlı bir ilişki olmadığını belirlemişlerdir. Karasu Avcı ve İbret (2016) ise okul öncesi öğretmen adaylarının vatanseverlik değerine ilişkin görüşlerinin belirlenmesini amaçladıkları çalışmada ise, öğretmen adaylarının çocuğa vatanseverlik değerini kazandırma ile bu değerin temelinin atılmasında okul öncesi öğretmenlerinin rolü olduğunu düşündüklerini saptamışlardır. Bu araştırmada ise, diğer araştırmalardan farklı olarak sadece okul öncesi öğretmen adaylarının okul öncesi dönemde değerler eğitimine yönelik görüşlerinin incelenmesi amaçlanmıştır. $\mathrm{Bu}$ amaç doğrultusunda okul öncesi öğretmen adaylarının değerler eğitimine yönelik görüşlerinin, okullarda uygulanmasının önemli olduğunu düşündükleri değerlerin ve bu değerlere yönelik kendilerini yeterli görüp görmediklerinin belirlenmesine çalışılmıştır.

\section{Yöntem}

\section{Araştırma Modeli}

$\mathrm{Bu}$ araştırmada okul öncesi öğretmen adaylarının değerler eğitimine yönelik görüşlerini belirmek amaciyla nicel araştırma modellerinden tarama modelinde 
gerçekleştirilmiştir. Tarama modeli, evren ile ilgili genel bir sonuca ulaşmada özellikle bir grupla yapılan çalışmalardır (Büyüköztürk, Çakmak, Akgün, Karadeniz ve Demirel, 2016).

\section{Örneklem}

Okul öncesi öğretmen adaylarının değerler eğitimine yönelik görüşlerini belirlemek için yapılan bu araştırmanın örneklemi ölçüt örnekleme yoluyla belirlenmiştir. Özel Öğretim Yöntemleri 1 ve 2 derslerini almış olmak, araştırmanın ölçütü olarak belirlenmiştir. Bu dersler, öğretmen adaylarının okul öncesi eğitim programını tanımalarına ve programda yer alan kazanım ve göstergelere bağlı olarak etkinlikler planlayabilmelerine dayanmaktadır. Okul öncesi eğitim programında saygı, sevgi, yardımlaşma ve işbirliği, iyilik ve hoşgörü, barış, özgüven, sorumluluk, dayanışma, paylaşma değerleri üzerinde özellikle durulmaktadır. Bu değerlere kazanım ve göstergelerde de yer verilmektedir. Öğretmen adaylarının bu dersleri aldıktan sonra değerler ve eğitimine ilişkin sorulara daha net cevaplar verebilecekleri düşünülmektedir. Bu nedenle özellikle Özel Öğretim Yöntemleri 1 ve 2 derslerini almış olan öğretmen adaylarının örnekleme dahil edilmesi sağlanmıştır. Araştırmanın örneklemini, 2018-2019 eğitim öğretim y1lında Eğitim Fakültesi Okul Öncesi Eğitimi Anabilim Dalında öğrenim görmekte olan 116 öğrenci oluşturmaktadır. Çalışmaya katılan öğrencilerden 6's1 erkek ve 110'u kız öğrencidir. Örneklemi oluşturan öğrencilerin 34'ü 3. sınıf ve 82 'si 4. sınıf öğrencilerinden oluşmaktadır. Katılımcıların yaş dağılımlarına bakıldığında 29 kişinin 20-21 yaş, 49 kişinin 22-23 yaş ve 38 kişinin 23 ve üzeri yaşta yer aldığ görülmektedir.

\section{Veri Toplama Araçları}

Araştırma verilerinin toplanmasında, araştırmanın amaçlarına uygun olarak hazırlanan değerler eğitimine yönelik görüş formu kullanılmıştır. Formun ilk bölümünde cinsiyet, yaş, sınıf gibi değişkenlere ilişkin bilgiler sorgulanmıştır. İkinci bölümünde ise değerler eğitimine ilişkin görüşlerin belirleyici sekiz açık uçlu soru yer almıştır. Görüş formunun geliştirilmesinde, hazırlanan taslak form iki alan uzmanın görüşüne sunularak kapsam geçerliği sağlanmaya çalış1lmıştır. Daha sonra iki öğretmen adayına anket uygulanmış ve soruların anlaşılabilirliği test edilmiştir.

Okul öncesi eğitimi öğretmen adaylarına yöneltilen sorular aşağıda yer almaktadır: 
1. Değerler eğitimi sizce nedir?

2. Okul öncesinde değerler eğitimi sizce önemli midir? Neden?

3. Değerler eğitimi denildiğinde aklınıza ilk olarak hangi değerler gelmektedir?

4. Okul öncesi çocuklarına kazandırılabilecek en kolay ilk üç değer hangileridir?

5. Okul öncesi çocuklarına kazandırılabilecek en zor ilk üç değer hangileridir?

6. Okul öncesi öğretmeni değerler eğitimini çocuklara sizce hangi yollarla verebilir?

7. Değerlerden hangisini ya da hangilerini her zaman hayatınızda ön planda tutmaya çalışırsınız?

8. Değerler eğitiminde verilmesi gereken değerlere uygun davrandığınızı düşünüyor musunuz?

\section{Verilerin Analizi}

Okul öncesi öğretmen adaylarının değerler eğitimine ilişkin görüşlerinin belirlenmesine yönelik olarak planlanan bu araştırma kapsamında görüş formundan elde edilen veriler frekans analizi yoluyla analiz edilmiş ve yüzde ve frekans tabloları halinde ifade edilmiştir.

\section{Bulgular}

Bu bölümde, araştırmadan elde edilen bulgular araştırmanın sorularına göre düzenlenerek sunulmuştur.

Araştırma kapsamına alınan 116 öğretmen adayından değerler eğitimine yönelik ders alan 6 ve ders almayan 110 öğretmen adayı vardır. Değerler eğitimine yönelik ders alan 6 adaydan 4'ü aldığ1 eğitimi yeterli görürken 2'si aldığı eğitimi yeterli görmemektedir.

Tablo 1'de okul öncesi öğretmen adaylarının "Değerler eğitimi sizce nedir?" sorusuna yönelik görüşleri yer almaktadır.

Tablo 1: “Değerler Eğitimi Sizce Nedir?” Sorusuna İlişkin Görüşler

\begin{tabular}{lll}
\hline Görüșler & $\mathrm{f}$ & $\%$ \\
\hline Evrensel Değerlerin Aktarılması & 31 & 28,2 \\
\hline Değerlerin Öğretimi İçin Verilir & 21 & 19,1 \\
\hline Toplumun Hoş Göreceği İnsani Davranışlar & 18 & 16,4 \\
\hline Kültüre Yönelik Ĕ̆itim & 17 & 15,5 \\
\hline Toplumsal Ahlaki Kurallar Bütünlüğü & 8 & 7,3 \\
\hline
\end{tabular}




\begin{tabular}{lll}
\hline Kültürü Davranışa Aktarma & 5 & 4,5 \\
\hline Ahlaki Gelişim İçin Davranışlar & 5 & 4,5 \\
\hline Kişilik Ve Davranış Eğitimi & 5 & 4,5 \\
\hline Toplam & 116 & 100 \\
\hline
\end{tabular}

Tablo 1'de görüldüğü gibi öğretmen adayları \%28,2 (n=31) oranında evrensel değerlerin aktarılması için, \%19,1 $(n=21)$ oranında değerlerin öğretimi için verildiğini, \%16,4 (n=18) oranında toplumun hoş göreceği insani davranışlar ve $\% 15,5(n=17)$ oranında ise kültüre yönelik eğitim olarak verildiğini ifade etmişlerdir.

$\mathrm{Bu}$ araştırma kapsamına alınan okul öncesi öğretmen adaylarının hepsi değerler eğitiminin okul öncesi dönemde önemli olduğunu ifade etmişlerdir.

Okul öncesinde değerler eğitiminin önemli olma nedenleri Tablo 2'de verilmiştir.

\begin{tabular}{lcl}
\hline Tablo 2: “Okul Öncesinde Değerler Eğitimi Önemli Midir? ” Sorusuna İlişkin Görüşler & \\
\hline Görüşler & $\mathrm{f}$ & $\%$ \\
\hline Kişilik gelişiminin en önemli yaş aralığı & 61 & 57,54 \\
\hline Topluma uyumu sağladığı için & 17 & 16,03 \\
\hline Değerler nasıı bir insan olunacağını belirler & 9 & 8,49 \\
\hline Topluma yararlı ve sağlıklı birey yetiştirmek & 7 & 6,60 \\
\hline Değerlere karşı farkındalık oluşturduğu için & 5 & 4,71 \\
\hline Çocukların bakış açısını genişlettiği için & 2 & 1,88 \\
\hline Çocuğun sosyalleşmesini sağladığı için & 2 & 1,88 \\
\hline Çocukları yakından tanımak için & 1 & 0,94 \\
\hline Çocuğun sorumluluk kazanmașı için & 1 & 0,94 \\
\hline Toplumu geliştirdiği için & 1 & 0,94 \\
\hline Toplam & 106 & 100 \\
\hline
\end{tabular}

Tablo 2'de okul öncesi eğitimi öğretmen adayları \%57,54 (n=61) oranında kişilik gelişiminin en önemli yaş aralığı olduğu için okul öncesinde değerler eğitiminin önemli olduğunu ifade etmişlerdir. Ayrıca \%16,03 (n=17) oranında çocuğun topluma uyumu sağladığı için, \%8,49 $(\mathrm{n}=9)$ oranında değerlerin nasıl bir insan olunacağını belirlediği ve $\% 6,60(n=7)$ oranında topluma yararlı ve sağlıklı bireyler yetiştirmek için okul öncesinde değerler eğitiminin önemli olduğunu ifade etmişlerdir.

\begin{tabular}{lll}
\hline $\begin{array}{l}\text { Tablo 3: “Değerler Eğitimi Denildiğinde Akla İlk Olarak Hangi Değerler Gelmektedir?” Sorusuna } \\
\text { İlişkin Görüşler }\end{array}$ & \multicolumn{1}{l}{} \\
\hline Görüşler & $\mathrm{f}$ & $\%$ \\
\hline Sayg1 & 73 & 21,59 \\
\hline Sevgi & 64 & 18,93 \\
\hline Hoşgörü & 40 & 11,83 \\
\hline Dürüstlük & 25 & 7,39 \\
\hline
\end{tabular}




\begin{tabular}{lll}
\hline Yardımlaşma & 20 & 5,91 \\
\hline Ahlak & 18 & 5,32 \\
\hline Paylaşma & 13 & 3,84 \\
\hline Adalet & 13 & 3,84 \\
\hline Sorumluluk & 11 & 3,25 \\
\hline Merhamet & 11 & 3,25 \\
\hline Empati & 8 & 2,36 \\
\hline İşbirliği & 7 & 2,07 \\
\hline Kültür & 6 & 1,77 \\
\hline Barış & 5 & 1,47 \\
\hline İyilik & 5 & 1,47 \\
\hline Dostluk & 4 & 1,18 \\
\hline İnanç & 3 & 0,88 \\
\hline Özgürlük & 3 & 0,88 \\
\hline Temizlik & 3 & 0,88 \\
\hline Misafirperverlik & 2 & 0,59 \\
\hline Eleştirel Düşünme & 2 & 0,59 \\
\hline Özgüven & 1 & 0,29 \\
\hline Uzlaşma & 1 & 0,29 \\
\hline Aile & 1 & 0,29 \\
\hline Toplam & 338 & 100 \\
\hline
\end{tabular}

Tablo 3'de görüldüğü üzere öğretmen adayları \%21,59 $(n=73)$ oranında sayg1 değerini akla gelen ilk değer olarak belirtmişlerdir. İkinci olarak \%18,93 $(n=64)$ oranında sevgi değerini söylemişlerdir. Ayrıca \%11,83 $(n=40)$ oranında hoşgörü ve \%7,39 $(n=25)$ oranında dürüstlük, \%5,91 $(n=20)$ oranında yardımlaşma, \%5,32 $(n=18)$ oranında ahlak değerleri yanıtlarını vermişlerdir.

Tablo 4: "Okul Öncesi Çocuklarına Kazandırılabilecek En Kolay İlk Üç Değer Hangileridir?" Sorusuna İlişkin Görüşler

\begin{tabular}{lll}
\hline Görüşler & f & $\%$ \\
\hline Sevgi & 72 & 23,38 \\
\hline Saygı & 59 & 19,16 \\
\hline Yardımlaşma & 31 & 10,06 \\
\hline Hoşgörü & 27 & 8,77 \\
\hline Dürüstlük & 21 & 6,82 \\
\hline Sorumluluk & 15 & 4,87 \\
\hline Paylaşma & 12 & 3,90 \\
\hline İşbirliği & 9 & 2,92 \\
\hline Temizlik & 8 & 2,60 \\
\hline İyilik & 7 & 2,27 \\
\hline Dostluk & 5 & 1,62 \\
\hline
\end{tabular}




\begin{tabular}{lll}
\hline Merhamet & 6 & 1,94 \\
\hline Adalet & 4 & 1,30 \\
\hline Güven & 4 & 1,30 \\
\hline Barış & 3 & 0,97 \\
\hline Empati & 3 & 0,97 \\
\hline Aile & 3 & 0,97 \\
\hline Milli Değerler & 3 & 0,97 \\
\hline Yaratıcılık & 2 & 0,65 \\
\hline Mutluluk & 2 & 0,65 \\
\hline Başarı & 2 & 0,65 \\
\hline Ahlak & 2 & 0,65 \\
\hline Sabır & 2 & 0,65 \\
\hline Misafirperverlik & 1 & 0,32 \\
\hline Özgürlük & 1 & 0,32 \\
\hline Kıskançlık & 1 & 0,32 \\
\hline Çevre Bilinci & 1 & 0,32 \\
\hline Emek & 1 & 0,32 \\
\hline Farkındalık & 1 & 0,32 \\
\hline Toplam & 308 & 100,0 \\
\hline
\end{tabular}

Tablo 4'e bakıldığında araştırmaya katılan okul öncesi öğretmen adayları 29 farklı değer belirtmişlerdir. Okul öncesi öğretmen adayları \%23,38 (n=72) oranında sevgi, $(n=59)$ oranında saygı ve $\% 10,06(n=31)$ oranında yardımlaşma cevaplarını vermişlerdir. Bu değerler göz önüne alındığında sevgi, saygı ve yardımlaşma okul öncesi çocuklarına kazandırılabilecek en kolay ilk üç değer olarak belirlenmiştir. Bu değerleri \%8,77 ( $\mathrm{n}=27)$ oranında hoşgörü, \%6,82 $(n=21)$ oranında dürüstlük ve $\% 4,87(n=15)$ oranında sorumluluk değerleri takip etmiştir.

Tablo 5: “Okul Öncesi Çocuklarına Kazandırılabilecek En Zor İlk Üç Değer Hangileridir?” Sorununa İlişkin Görüşler

\begin{tabular}{lll}
\hline Görüşler & $\mathrm{f}$ & $\%$ \\
\hline Empati & 27 & 11,95 \\
\hline Sayg1 & 26 & 11,50 \\
\hline Dürüstlük & 24 & 10,62 \\
\hline Hoşgörü & 20 & 8,85 \\
\hline Adalet & 18 & 7,96 \\
\hline Merhamet & 11 & 4,87 \\
\hline Sorumluluk & 11 & 4,87 \\
\hline Vicdan & 9 & 3,98 \\
\hline Sabır & 8 & 3,54 \\
\hline Özgüven & 8 & 3,54 \\
\hline Paylaşma & 8 & 3,54
\end{tabular}




\begin{tabular}{lll}
\hline Barış & 7 & 3,10 \\
\hline Alçakgönüllülük & 6 & 2,65 \\
\hline Özdenetim & 6 & 2,65 \\
\hline Sevgi & 5 & 2,21 \\
\hline Vatan Sevgisi & 4 & 1,77 \\
\hline İşbirliği & 4 & 1,77 \\
\hline İnanç/Ahlak & 4 & 1,77 \\
\hline Fedakârlık & 3 & 1,33 \\
\hline Yardımlaşma & 3 & 1,33 \\
\hline Misafirperverlik & 2 & 0,88 \\
\hline Özgürlük & 2 & 0,88 \\
\hline Samimiyet & 2 & 0,88 \\
\hline Temizlik & 1 & 0,44 \\
\hline Güven & 1 & 0,44 \\
\hline Kültür & 1 & 0,44 \\
\hline Uzlaşma & 1 & 0,44 \\
\hline İletişim & 1 & 0,44 \\
\hline Cesaret & 1 & 0,44 \\
\hline Kötülük & 1 & 0,44 \\
\hline Karamsarlık & 1 & 0,44 \\
\hline Toplam & 226 & 100,0 \\
\hline
\end{tabular}

Tablo 5'te araştırmaya katılan öğretmen adayları tarafından 31 farklı değerin ifade edildiği görülmektedir. Bu görüşlerin 77'sinin “empati, sayg1 ve dürüstlük” değerlerine ait olduğu belirlenmiştir. Öğretmen adayları \%11,95 ( $\mathrm{n}=27)$ oranında empati, \%11,50 $(n=26)$ oranında sayg1 ve \%10,62 $(n=24)$ oranında dürüstlük cevaplarını vermişlerdir. Sonuçlar doğrultusunda okul öncesi çocuklarına kazandırılabilecek en zor ilk üç değer kategorisine sırasıyla "empati, sayg1 ve dürüstlük" değerleri girmektedir. Bunları sırasıyla \%8,85 $(n=20)$ oranında hoşgörü, \%7,96 (n=18) oranında adalet ve \% 4,87 (n=11) oranında merhamet ve sorumluluk değerleri takip etmektedir.

Tablo 6: “Okul Öncesi Öğretmeni Değerleri Çocuklara Hangi Yollarla Verebilir?” Soruna İlişkin Görüşler

\begin{tabular}{lll}
\hline Görüşler & $\mathrm{f}$ & $\%$ \\
\hline Yaratıcı Drama & 55 & 25,70 \\
\hline Oyun Yoluyla & 49 & 22,90 \\
\hline Türkçe Etkinliği & 29 & 13,55 \\
\hline Tüm Etkinliklerle & 25 & 11,68 \\
\hline Model Olma & 11 & 5,14 \\
\hline Örnek Olay & 9 & 4,21 \\
\hline Müzik Etkinliği & 9 & 4,21 \\
\hline Yaparak Yaşayarak Öğrenme & 8 & 3,74 \\
\hline Çizgi Film & 6 & 2,80 \\
\hline Görsel Materyaller & 4 & 1,87 \\
\hline Gezi & 3 & 1,40 \\
\hline
\end{tabular}




\begin{tabular}{lll}
\hline Sanat Etkinliği & 2 & 0,93 \\
\hline Ödül & 1 & 0,47 \\
\hline Aile Katılımı & 1 & 0,47 \\
\hline Görev Vermek & 1 & 0,47 \\
\hline Örtük Eğitim & 1 & 0,47 \\
\hline Toplam & 214 & 100,0 \\
\hline
\end{tabular}

Tablo 6' da araştırmaya katılan öğretmen adaylarının değerler eğitiminin çocuklara \%25,70 $(n=55)$ oranında yaratıcı drama, \%22,90 $(n=49)$ oranında oyun yoluyla ve \%13,55 (n=29) oranında ise Türkçe etkinliği ile verilebileceğini belirtmişlerdir. Ayrıca \%11,68 ( $\mathrm{n}=25)$ oranında tüm etkinlikler cevabını vermişlerdir. Bunları sırasıyla model olma, örnek olay, müzik etkinliği, yaparak yaşayarak öğrenme, çizgi film, görsel materyaller ve gezi takip etmektedir.

Tablo 7: "Değerlerin Hangisini ya da Hangilerini Her Zaman Hayatınızda Ön Planda Tutmaya Çal1şırsınız? " Sorusuna İlişkin Görüşler

\begin{tabular}{|c|c|c|}
\hline Görüşler & $\mathrm{f}$ & $\%$ \\
\hline Sayg1 & 63 & 28,51 \\
\hline Sevgi & 37 & 16,74 \\
\hline Hoşgörü & 25 & 11,31 \\
\hline Dürüstlük & 20 & 9,05 \\
\hline Adalet & 16 & 7,24 \\
\hline Empati & 12 & 5,43 \\
\hline Yardımlaşma & 10 & 4,52 \\
\hline Sorumluluk & 6 & 2,71 \\
\hline Hepsi & 6 & 2,71 \\
\hline Merhamet & 3 & 1,36 \\
\hline Ahlak & 3 & 1,36 \\
\hline Barış & 2 & 0,90 \\
\hline Paylaşma & 2 & 0,90 \\
\hline Temizlik & 1 & 0,45 \\
\hline Özgüven & 1 & 0,45 \\
\hline Vatan Sevgisi & 1 & 0,45 \\
\hline Misafirperverlik & 1 & 0,45 \\
\hline Sorgulama & 1 & 0,45 \\
\hline Ön Yargılı Olmama & 1 & 0,45 \\
\hline Vicdan & 1 & 0,45 \\
\hline Dostluk & 1 & 0,45 \\
\hline Doğayı Koruma & 1 & 0,45 \\
\hline Özgürlük & 1 & 0,45 \\
\hline Alçakgönüllülük & 1 & 0,45 \\
\hline İyilik & 1 & 0,45 \\
\hline Güven & 1 & 0,45 \\
\hline
\end{tabular}




\begin{tabular}{lll}
\hline Emek & 1 & 0,45 \\
\hline Mutluluk & 1 & 0,45 \\
\hline Sadakat & 1 & 0,45 \\
\hline Toplam & 221 & 100,0 \\
\hline
\end{tabular}

Tablo 7'de araştırmaya katılan öğretmen adaylarının hangi değerleri hayatınızda ön planda tutmaya çalışırsınız sorusuna \%28,51 $(\mathrm{n}=63)$ oranında ilk s1rada sayg1, \%16,74 $(n=37)$ oranında sevgi ve \%11,31 $(n=25)$ oranında hoşgörü ve $\% 9,05(n=20)$ oranında dürüstlük değeri yanıtını vermişlerdir. Bu değerleri sırasıyla adalet, empati, yardımlaşma, sorumluluk ve hepsi gibi yanıtlar takip etmiştir.

\begin{tabular}{lll}
\hline $\begin{array}{l}\text { Tablo 8: “Değerler Eğitiminde Verilmesi Gereken Değerlere Uygun Davrandığınızı Düşünüyor } \\
\text { Musunuz?" Sorusuna İlişkin Görüşler }\end{array}$ \\
\hline Görüşler & $\mathrm{f}$ & $\%$ \\
\hline Çoğu Zaman & 41 & 47,67 \\
\hline Evet & 26 & 30,23 \\
\hline Bazen & 9 & 10,47 \\
\hline Model Olmak İçin Evet & 5 & 5,81 \\
\hline İnsan Ve Öğretmen Olarak Evet & 3 & 3,49 \\
\hline Topluma Göre Değerler Değiștiği İçin Hayır & 1 & 1,16 \\
\hline Değerler İçselleştirilmediği İçin Hayır & 1 & 1,16 \\
\hline Toplam & 86 & 100,0
\end{tabular}

Tablo 8'de araştırmaya katılan öğretmen adaylarının değerlere uygun davranıp davranmadıklarına \%47,67 $(n=41)$ oranında çoğu zaman, \%30,23 (n=26) oranında evet ve \%10,47 (n=9) oranında bazen cevaplarını vermişlerdir. Bu görüşleri sırasıyla "model olmak için evet", "insan ve öğretmen olarak evet" ve "topluma göre değerler değiştiği ve içselleştirilmediği için hayır” yanıtları takip etmiştir.

\section{Tartışma}

Bu araştırmada okul öncesi öğretmen adaylarının değerler ve değerler eğitimine yönelik görüşleri incelenmiştir. Araştırmaya katılan öğretmen adaylarının çoğunluğunun değerler eğitimini evrensel değerlerin aktarılması olarak tanımlamas1, MEB (2015) Değerler Eğitimi Yönergesi maddelerinden "Değerlerimizin gelecek nesillere aktarılmasındaki önemli görevi yerine getirerek artan ve değişen risk ve tehditlerden bireysel ve toplumsal korunmayı sağlamak" maddesi ile örtüşmektedir. Uzun ve Köse (2017)’ye göre değerler eğitimi, insani değerlerin özümsenmesidir. Okul öncesi eğitimi; çocuğu, özelliklerine ve gelişimine göre zengin uyarıcılarla kültürel değerlere uygun hazırlayan kapsamlı bir süreçtir. 
Aynı zamanda okul öncesi dönem kritik bir dönem olduğu için çocuklara verilecek eğitim ileriki yaşamlarına yatırım olmaktadır (Kartal, 2008; Dereli İman, 2014). Karakaş (2015) değerler eğitiminin amacına ilişkin olarak okul öncesi öğretmenlerinin sırasıyla bireysel temelli, toplum temelli, ahlaki gelişim temelli ve milli kültürel değerler temelli olarak görüşlerini ortaya koyduklarını ifade etmektedir. Bu araştırma sonucuna göre ise, öğretmen adaylarının yarısından fazlası okul öncesinde değerler eğitimini, bu dönem kişilik gelişiminde en önemli yaş aralığ1 olduğu için önemli bulmaktadır. Uzun ve Köse (2017) de araştırmalarında değerler eğitiminin okul öncesi eğitimde verilmesinin gerekli olduğunu ve değerlerin kişilik gelişimini doğrudan etkilediğini ortaya koymuşlardır. Değer yarg1ları, eğitim ile gelişmekte ve nesilden nesile aktarılmaktadır (Özdemir, Boydak Özan ve Akgün, 2017). Değerler eğitimine erken dönemde başlanması ve anne babalar ile öğretmenlerin rol model olmasının çocuğun değerleri içselleştirmesinde önemli olduğu söylenebilmektedir. Bu açıdan okul öncesi öğretmen adaylarının değerler eğitiminin önemini okul öncesi eğitimin önemi ile ilişkilendirdikleri söylenebilir.

Okul öncesi öğretmen adayları, değerler eğitimi kapsamında ilk akla gelen değerlerin sırasıyla; sayg1, sevgi, hoşgörü, dürüstlük ve yardımlaşma olarak ifade etmişlerdir. Ayrıca okul öncesi öğretmen adaylarının okul öncesi çocuklarına kazandırılabilecek en kolay ilk üç değerin "sevgi, saygı yardımlaşma" ve en zor ilk üç değerin ise "empati, sayg1, dürüstlük" olarak ifade ettikleri belirlenmiştir. Çengelci, Hancı ve Karaduman (2013) araştırmalarında, okullarda sevgi, saygı, hoşgörü, dayanışma ve sorumluluk değerlerinin ön plana çıktığını ifade etmişlerdir. Tarkoçin, Berktaş ve Uyanık Balat (2013) okul öncesi öğretmenlerinin etkinlikler yoluyla çocuklara en çok sorumluluk, yardımlaşma, nezaket, sabır ve saygı değerlerini, en az ise hoşgörü, merhamet, sevgi/şefkat, doğruluk, paylaşma, işbirliği ve adalet değerlerini verdiklerini ifade etmektedirler. Öğretmelerin yaptığı değer tercihleri, tutumları ve sergiledikleri davranışları çocuklara verilen değerler eğitiminde önemli yer tutmaktadır (Uzun ve Köse, 2017). Okul öncesi öğretmenleriyle yapılan araştırmalar değerler eğitimi denildiğinde akla ilk olarak hoşgörülü olmak, işbirliği, yardımlaşma/yardımseverlik, sevgi, saygı, sorumluluk almak, dürüstlük ve nezaket değerlerinin geldiğini ortaya koymaktadır (Kozikoğlu, 2018; Ogelman ve Sarıkaya, 2015; Sapsağlam ve Ömeroğlu, 2015; Tarkoçin, Berktaş,Uyanık Balat 2013; Uzun ve Köse, 2017; Yazar ve Erkuş, 2013). Aral ve Kadan (2018) araştırmasında, Okul Öncesi Eğitim Programı (MEB, 2013)'nı kazanım ve göstergelere göre değerler açısından incelemiş ve sırasıyla sorumluluk, saygı, dayanışma, güven, sevgi değerlerinin 
daha çok; hoşgörü, özgürlük, eşitlik, dostluk ve adalet değerlerinin ise kazanım ve göstergelerde daha az yer aldığını bulmuşlardır. Çetingöz'ün (2015) araştırması ise, girişimcilik, barış, özdenetim, özsaygı, cesaret, sabır ve iletişim değerlerinden bahsedilmediğini ortaya koymuştur. Değerler, bireylerin düşünce, tutum ve davranışlarının şekillenmesinde önemli yere sahiptir (Yılmaz, 2009). Değerlerin eğitiminde öğretmenler, sınıfı öğrenme ortamlarına dönüştürerek ve öğrencilere rol model olarak onların kişisel gelişimlerine önemli katkılar sağlamaktadırlar (Yıldırım, 2009; Balıkcı, 2016). Okul öncesi dönemde çocuklar taklit yoluyla öğrendikleri için öğretmenlerin rol model olarak kendi öz-değerlerini gözden geçirmesi önemlidir (Maya, 2017). Sarı (2005), eğitim fakültesi öğrencileri üzerindeki araştırmasında öğrencilerin değer tercihlerinin önem s1rasını siyasi, genel ahlak, dinî, ekonomik, estetik, sosyal ve bilimsel şeklinde ortaya koymuştur. Zavalsız (2014) farklı bölümlerden üniversite öğrencileri ile yaptığı araştırmada öğrencilerin değer önceliklerini sırasıyla dini, ahlaki, sosyal, siyasi, estetik, teorik-bilimsel ve ekonomik değerler şeklinde ortaya çıkarmıştır. Yapılan bir araştırmada farklı bölümlerden öğretmen adaylarının değer yargıları, Fen ve Teknoloji Öğretmenliği güç, başarı, uyarılım; İngilizce Öğretmenliği hazcılık; Din Kültürü ve Ahlak Bilgisi Öğretmenliği evrensellik, geleneksellik ve iyilikseverlik; Felsefe Öğretmenliği başarı, iyilikseverlik, uyma ve güvenlik; Sınıf Öğretmenliği evrensellik; Bilgisayar Öğretmenliği öz yönelim şeklinde öne çıkmaktadır (Yapıcı, Kutlu ve Bilican, 2012). Oikonomou ve Marusic (2013) ise yaptıkları araştırmada Sırp öğretmen adaylarının en önemli değerlerinin hayırseverlik ve evrenselcilik olduğunu ortaya koymuştur. Evrensel değerlerden bazıları paylaşma, empati, güvenilirlik, alçakgönüllülük, anlayış, bağışlayıcılık, saygı, arkadaşlık, bağlılık, sorumluluk, barış, cesaret, cömertlik, doğruluk, dostluk, sevgi, düşünceli olma, hoşgörü, istikrarlı olma, işbirliği, tutumluluk, itaat, adalet, iyilikseverlik, kanaatkârlık, yardımseverlik, liderlik, merhamet, sadakat, disiplin, nezaket, özgüven, sabır, şükran, vefa, söz ve davranışlarda tutarlılık, yaşama sevinci gibi değerlerdir (Aydın, 2010). Bu araştırma sonucunda öğretmen adaylarının değerler eğitimi denilince akla gelen değerler arasında işbirliği, barış, dostluk, özgüven gibi değerlere az yer verdikleri belirlenmiştir. Ayrıca öğretmen adayları bazı terimleri de değer olarak ifade etmişlerdir. Örneğin; özbakım becerisi olan temizliği, yine bir beceri olan eleştirel düşünmeyi ve örfleri, adetleri, maddi ve manevi olarak toplumun yaşattı̆̆ her şeyi içine alan kültürü değer olarak ifade etmişlerdir. Yine kıskançlık, kötülük, karamsarlık gibi kişilere özgü olumsuz davranışları da değer olarak belirtmişlerdir. Bu davranışların kazandırılması değil, çocukların bu davranış- 
lardan uzak durması öğretilmelidir. Oranlar az olsa da bu sonuç, okul öncesi öğretmen adaylarının değerler konusunda desteklenmeye ihtiyaçları olduğunu da düşündürmektedir.

$\mathrm{Bu}$ araştırmada öğretmen adayları genellikle kendilerini değer sahibi olarak gördüklerini ifade etmişlerdir. Değerler Eğitiminin amacı evrensel değerler ile bireyleri ahlâkî değerlere sahip karakterli, sorumluluk duygusu kazanmış kişiler yetiştirmek ve dünyanın yaşanılır hale gelmesine katkı sağlamaktır (Altan, 2011; Kulaksızoğlu ve Dilmaç, 2000). Okul öncesi dönemde çocuk, değerleri öğretmeninden görerek sevmekte ve bu değerleri davranışa dönüştürerek öğrenmektedir. Bu sebeple öğretmenlerin değer sahibi olması ve rol model olması gerekmektedir.

Okul öncesi dönemde çocuklara değerler eğitimi öğretiminde drama, oyun, geziler ve farklı etkinliklerden yararlanabilir. Pekdoğan ve Korkmaz (2017) farklı yöntemlerle yapılan etkinliklerin çocukların sorumluluk almasında ve gelişim alanlarının ilerlemesinde faydalı olduğunu ifade etmektedirler. Araştırma sonucunda, araştırmaya katılan öğretmen adaylarının değerler eğitimini çocuklara toplam 16 farklı yolla verilebileceğini ifade ettikleri görülmüştür. En çok verilen cevaplar "yaratıcı drama, oyun, Türkçe etkinliği, tüm etkinlikler ve model olma" olmuştur. Değerlerin soyut kavramlar olması nedeniyle okul öncesi çocukların gelişimsel özellikleri de dikkate alınarak organize edilmiş iyi bir yapı ile kazandırılması gerekmektedir (Uzun ve Köse, 2017). Thornberg (2008) araştırmasında değerler eğitiminin, öğrencilerin okuldaki günlük davranışlarına odaklanarak çoğunlukla plansız olarak bilinçsizce yapıldığını ortaya koymuştur. Dollinger, Philip ve Nathaniel (2007), araştırması sonucunda, yaratıcıllğın değerlere dayandığı görüşünü ortaya koymaktadır. Kozikoğlu (2018) ise çalışmasında, değer eğitiminde öğretmenlerin drama, oyun ve Türkçe etkinlikleri, sanat etkinlikleri, görsel ve işitsel etkinlikler gerçekleştirdikleri sonucuna ulaşmıştır. Diğer araştırmalarda öğretmenlerin, değerler eğitimi sırasında okul öncesi etkinliklerinde en fazla drama ve Türkçe etkinliklerine daha sonra müzik, oyun, sanat, alan gezisi ve okuma yazmaya hazırlık etkinliklerine yer verdikleri görülmektedir (Sapsağlam ve Ömeroğlu, 2015; Karakaş, 2015; Uzun ve Köse, 2017). Thompson (2011) ise, değer eğitiminde hikâye anlatımı gibi yöntemlerin öğretmenler tarafından kullanıldığını ortaya koymuştur. Aynı zamanda Can Aral ve Demirel (2013) yaptıkları araştırmada öğretmenlerin sosyal bilgiler dersinde sorumluluk değerini model olma, yaratıcı drama yöntemleri kullanarak verdiklerini belirtmektedirler. Değerler eğitiminde eğitici oyunlar, rol oynama 
yöntemi ve gösteri tekniği kullanılabilecek diğer yöntemlerdir (Akto ve Akto, 2017). Farklı bölümler üzerine yapılan araştırmalara bakıldığında ise, öğretmenler sosyal bilgiler dersinde örnek olay yöntemi kullanarak en çok hoşgörü değerini kazandırmaktadırlar (Aslan, 2016). Bu araştırmada aile katılımının değerlerin öğretiminde bir kişi tarafından cevap olarak verilmiştir. Oysa aile katılımı çocukların kalıcı olarak öğrenmelerinin desteklenmesinde önemlidir. $\mathrm{Bu}$ nedenle aile katılımı çalışmalarıyla beraber verilen değerler eğitiminin değerlerin içselleştirilmesinde önemli olacağı düşünülmektedir. Yapılan bazı çalışmalar, okul öncesi öğretmenlerinin, programda yer alan değerler eğitiminin yetersiz olması, aile katılımının olmaması ve bütün sorumluluğun öğretmenlere bırakılması gibi güçlüklerin değerler eğitiminin verilmesini engellediği görüşünü ortaya koymaktadırlar (Yazar ve Erkuş, 2013; Aslan, 2016).

\section{Sonuç ve Öneriler}

$\mathrm{Bu}$ araştırma sonucunda araştırmaya katılan öğretmen adaylarının çoğunluğunun değerler eğitimini evrensel değerlerin aktarılması olarak tanımladıkları ve kişilik gelişiminin en önemli yaş aralığı olduğu için okul öncesinde değerler eğitiminin önemli olduğunu ifade ettikleri belirlenmiştir. Ayrıca okul öncesi öğretmen adayları okul öncesi dönemde öğretilebilecek en kolay değerlerin sevgi, saygı ve yardımlaşma olduğunu, empati, saygı ve dürüstlük değerlerinin ise zor öğretilebileceğini ifade etmişlerdir. Araştırmaya katılan öğretmen adaylarının değerler eğitiminin çocuklara yaratıcı drama, oyun yoluyla ve Türkçe etkinliği ile verilebileceğini ifade ettikleri de saptanmıştır. Değerler eğitimi Okul Öncesi Programı içerisinde farklı etkinliklerde ve yaşamsal becerilerle verilebilir. Ayrıca öğretmen adaylarının saygı değerini hem kolay hem de zor öğretilebilecek bir değer olarak görmeleri, aslında değerler eğitimi konusunda çok fazla bilgiye sahip olmadıklarını da düşündürmektedir. Bu araştırma sonucunda öğretmen adaylarının hayatlarında sırasıyla saygı, sevgi, hoşgörü ve dürüstlük değerlerine öncelik verdikleri ortaya çıkmıştır. Aynı zamanda okul öncesi öğretmen adayları değerler eğitiminde verilmesi gereken değerlere uygun davrandıklarını ifade etmişlerdir. Ancak okul öncesi öğretmen adaylarının bazı becerileri ve kavramları da değerler içerisine aldıkları da görülmektedir. Bu araştırma kapsamına alınan öğretmen adaylarının çoğunluğu değerler ve eğitimine yönelik bir ders almamışlardır. $\mathrm{Bu}$ açıdan öğretmen adaylarının değerleri nasıl öğretebileceklerini görebilmeleri açısından üniversitelerde değerler eğitimine yönelik uygulamalı derslerin verilmesi gerektiği düşünülmektedir. Ayrıca aldıkları bu derslerin 
bilgi ve düşüncelerinde farklılığa yol açıp açmadıklarının inceleneceği deneysel çalışmalar yapılması önerilebilir.

Okul öncesi öğretmen adaylarının değerler eğitimine uygun davrandıklarını belirtmeleri önemli bir sonuçtur. Ancak öğretmen adaylarının özellikle Öğretmenlik Uygulaması derslerinde gözlemlenip uygulama boyutunda değerler eğitimine uygun davranıp davranmadıklarının belirlenmesinin de önemli olduğu düşünülmektedir. Böylece düşüncelerin davranışa dönüştürülmesi de sağlanmış olacaktır.

\section{Kaynakça}

Akbaş, O. (2008). Değer eğitimi akımlarına genel bir bakış. Değerler Eğitimi Dergisi, 6(16) 9-27.

Akto, A. \& Akto, S. (2017). Okul öncesi değerler eğitiminde kullanılan yöntem ve teknikler (nitel bir araştırma). Şarkiyat Illmi Araştırmalar Dergisi/Journal of Oriental Scientific Research, 9(2), 1074-1095.

Altan, M.Z. (2011). Çoklu zekâ kuramı ve değerler eğitimi. Pegem Eğitim ve Öğretim Dergisi, 1(4), 54-57.

Aral, N. \& Kadan, G. (2018). 2013 Okul öncesi eğitim programının değerler eğitimi bağlamında incelenmesi. Erken Çocukluk Çalışmaları Dergisi, 2(1), 113-131.

Aslan, S. (2016). Sosyal bilgiler öğretmenlerinin değerler eğitimi ile ilgili görüşlerinin incelenmesi. International Journal Of Eurasia Social Sciences, 7(25), 203-227.

Aydın, M. Z. (2010). Okulda değerler eğitimi. Eğitime Bakış, 6(18), 16-19.

Aydın, E. \& Sulak, S. E. (2015). Sınıf öğretmeni adaylarının “değer” kavramına yönelik metafor algıları. Bartın Üniversitesi Eğitim Fakültesi Dergisi, 4(2), 482-500.

Bakan, T. (2018). Değerler eğitim programının anasınıfina devam eden çocukların değer kazanımı üzerine etkisinin incelenmesi (Yüksek lisans tezi). İstanbul Üniversitesi Eğitim Bilimleri Enstitüsü, İstanbul.

Balıkcı, G. N. (2016). Erken çocukluk döneminde değerler ve ahlak eğitimimin yeri ve önemi. A. Güvenç Saygın \& M. Saygın (Yay. haz.), Eğitimde Gelecek Araylşlart: Dünden Bugüne Türkiye'de Beceri, Ahlak ve Değerler Eğitimi Uluslararası Sempozyumu (s.101-113). Ankara: Atatürk Araştırma Merkezi Yayınları.

Başal, H.A., Çelebi, M. \& Malak, H. (2016). Okul öncesi öğretmen adaylarında denetim odağı ve insani değerler ilişkisi. International Journal of Human Sciences, 13(1), 198-208. 
Bozdaş, Ş. (2013). Öğretmenlerin mesleklerine adanmışlık düzeyleri ile değgerler eğitimi uygulama düzeyleri arasındaki ilişki (Yüksek lisans tezi). Ankara Hacettepe Üniversitesi Eğitim Bilimleri Enstitüsü, Ankara.

Büyüköztürk, S. Çakmak, E.K., Akgün, O.E., Karadeniz, S. \& Demirel, F. (2016). Bilimsel araştırma yöntemleri. Ankara: Pegem.

Can Aral, Ö. \& Demirel, Ö. (2013). Dördüncü ve beşinci sınıf öğretmenlerinin sosyal bilgiler dersinde değerler eğitimi uygulamalarına ilişkin görüşleri. Elektronik Sosyal Bilimler Dergisi, 12(46), 151-168.

Costanzo, R. A. (2005). A study of character education programs in Connecticut public elementary schools based on the eleven principles of effective character education. University of Bridgeport, USA: ProQuest Dissertations.

Cottom, C. (1996). In India a bold experiment in teaching values. International Service Learning \& Community Engagement, 53(8), 54-58.

Çengelci, T., Hancı, B. \& Karaduman, H. (2013). Okul ortamında değerler eğitimi konusunda öğretmen ve öğrenci görüşleri. Değerler Eğitimi Dergisi, 11(25), 33-56.

Çetingöz, D. (2015). Okul öncesi eğitimi öğretmen adaylarının değerler eğitimde öğretmenin rolüne ilişkin görüşleri. Türkiye Sosyal Araştırmalar Dergisi, 19(3), 33-52.

Demircioğlu, İ. H. \& Tokdemir, M. A. (2008). Değerlerin oluşturulma sürecinde tarih eğitimi: amaç, işlev ve içerik. Değerler Eğitimi Dergisi, 6(15), 69-88.

Dereli İman, E. (2014). Değerler eğitimi programının 5-6 yaş çocuklarının sosyal gelişimine etkisi: sosyal beceri, psikososyal gelişim ve sosyal problem çözme becerisi. Kuram ve Uygulamada Eğitim Bilimleri, 14 (1), 249-268.

Dilmaç, B. (2007). Bir grup fen lisesi öğrencisine verilen insani değerler eğitiminin insani değerler ölçeği ile sınanması (Doktora tezi). Selçuk Üniversitesi Sosyal Bilimler Enstitüsü, Konya.

Dilmaç, B., Bozgeyikli, H. \& Çıkılı, Y. (2008). Öğretmen adaylarının değer alg1larının farklı değişkenler açısından incelenmesi. Değerler Ĕgitimi Dergisi, 6(16), 69-91.

Dollinger, S. J., Philip A. B. \& Nathaniel W. G. (2007). Creativity and values. Creativity Research Journal, 19(2-3), 91-103.

Ekşi, H. (2003). Temel insanî değerlerin kazandırılmasında bir yaklaşım: karakter eğitimi programları. Değerler Ĕ̆itimi Dergisi, 1(1), 79-96.

Erikli, S. (2016). Okul öncesi çocukları için bir değerler eğitimi programının geliştirilmesi ve uygulanması (Yüksek lisans tezi). Orta Doğu Teknik Üniversitesi, Ankara. 
Grimbilas, J. (2009). The effect of a character education unit on the behavior of ninth grade students. Unpublished master'a thesis, Graduate Program Caldwell College, New Jersey, USA.

Güneş, F. (2016). Değerler Eğitiminde Yaklaşım ve Modeller. A. Güvenç Saygın, \& M. Saygın (Yay. haz.), Ĕgitimde Gelecek Arayışları: Dünden Bugüne Türkiye'de Beceri, Ahlak ve Değerler Ĕgitimi Uluslararası Sempozyumu (s. 1-20). Ankara: Atatürk Araştırma Merkezi.

Huşu, J. \& Tirri, K. (2007). Developing whole school pedagogical values - A case of going through the ethos of "good schooling". Teaching and Teacher Education, 23(4), 390-401.

Karakaş, H. (2015). Değerler eğitimi etkinliklerinin okul öncesi öğretmenlerine göre değerlendirilmesi: nitel bir çalışma. A. Güvenç Saygın \& M. Saygın (Yay. haz.),Eğitimde Gelecek Arayışlarl: Dünden Bugüne Türkiye'de Beceri, Ahlak ve Değerler Ĕgitimi Uluslararası Sempozyumu (s. 623-649). Ankara: Atatürk Araştırma Merkezi.

Karasu Avc1, E. \& İbret, B. Ü. (2016). Vatanseverlik değerine ilişkin okul öncesi öğretmen adaylarının görüşlerinin incelenmesi. Kastamonu Eğitim Dergisi, 24(5), 2501-2518.

Kartal, H. (2008). Erken çocukluk eğitiminin gerekliliği ve önemi: Geçmişten günümüze erken çocukluk uygulamaları. Bursa: Ezgi Kitabevi.

Kasapoğlu, H. (2013). Okulda değerler eğitimi ve hikayeler. Millî Eğitim, 198, 97-109.

Katılmış, A., Ekşi, H. \& Öztürk, C. (2011). Efficiency of social studies integrated character education program. Educational Sciences: Theory and Practice, 11(2), 854-859.

Kolaç, E. \& Karadağ, R. (2011). Türkçe öğretmeni adaylarının “değer” kavramına yükledikleri anlamlar ve değer sıralamaları. İlköğretim Online, 11(3), 762-777.

Kozikoğlu, İ. (2018). Okul öncesi öğretmenlerinin değerler eğitimine ilişkin tutum ve görüşlerinin incelenmesi. Uluslararası Türkçe Edebiyat Kültür Eğitim Dergisi, 7(4), 2698-2720.

Kulaksızoğlu, A. \& Dilmaç, B. (2000). İnsani değerler eğitimi program1. M.Ü. Atatürk Eğitim Fakültesi Eğitim Bilimleri Dergisi, 12, 199-208.

Kurtdede, N. F. (2009). Öğretmen adaylarının değer öğretimine ilişkin gö r üş le ri. Kuramsal Ë̆itimbilim Dergisi, 2(2), 1-18.

Kurtulmuş, M., Tösten, R. \& Gündaş, A. (2014). İlköğretim 1. kademe öğretmenlerinin değerler eğitimi sürecinde karşılaştıkları sorunlar. Değerler Eğitimi Dergisi, 12(27), 281-305. 
Kuzu, K. (2015). Okul öncesi ögrretmenlerinin değerler eğitimi hakktndaki görüşleri ve bu görüşlerin sinıf içi uygulamalara yansıması (Yüksek lisans tezi). Bursa Uludağ Üniversitesi Eğitim Bilimleri Enstitüsü, Bursa.

Maya, İ. (2017). Türk devlet okullarında çalışan okul öncesi öğretmenlerinin öz değerleri. Eğitim Araştırmast ve İncelemeleri, 12(11), 595-603.

MEB (2013). Okul öncesi eğitim programı. Ankara: Vize.

MEB (2015) Değerler Eğitimi Yönergesi İkinci bölüm/Uygulama ilke ve esasları. (2019, 10 Haziran) Erişim adresi:http://mebk12.meb.gov.tr/meb_iys_dosyalar/34/39/749197/dosyalar/2015_02/09093609_degerleregitimi.pdf

Meydan, H. (2012). İlköğretim okullarında değerler ve karakter eğitimi, (Doktora Tezi). Sakarya Üniversitesi Sosyal Bilimler Enstitüsü, Sakarya.

Neslitürk, S. (2013). Anne değerler eğitimi programının 5-6 yaş çocuklarının sosyal beceri düzeyine etkisi (Yayınlanmamış doktora tezi). Selçuk Üniversitesi Sosyal Bilimler Enstitüsü, Konya.

Ogelman, H. G. \& Sarıkaya, H. E. (2015). Okul öncesi eğitimi öğretmenlerinin değerler eğitimi konusundaki görüşleri: Denizli ili örneği. Sakarya Üniversitesi Eğitim Fakültesi Dergisi, 29, 81-100.

Oğuz, E. (2012). Öğretmen adaylarının değerler ve değerler eğitimine ilişkin görüşleri. Kuram ve Uygulamada Eğitim Bilimleri, 1310-1325.

Oikonomou, A. \& Marusic, M. (2013). Value hierarchy of future subject teachers in Serbia in the context of Schwartz theory. Directory of Open Access Journals 45(2), 241-259.

Özdemir, T. Y., Boydak Özan, M. \& Akgün, M. (2017). Öğretmen görüşleriyle değerler eğitimi odaklı eğitim denetimi. Bartın Üniversitesi Eğitim Araştırmaları Dergisi, 1(1), 35-52.

Öztürk Samur, A. (2011). Değerler eğitimi programının 6 yaş çocuklarının sosyal ve duygusal gelişimlerine etkisi (Doktora tezi). Konya Selçuk Üniversitesi Sosyal Bilimler Enstitüsü, Konya.

Pekdoğan, S., Korkmaz, H. İ. (2017). Okul öncesi eğitime devam eden 5-6 yaş çocuklarına verilen değerler eğitimine ilişkin öğretmen görüşlerinin incelenmesi. Mustafa Kemal Üniversitesi Sosyal Bilimler Enstitüsü Dergisi, 14(37), 59-72.

Revell, L., \& Arthur, J. (2007). Character education in schools and the education of teachers. Journal of Moral Education, 36(1), 79-92.

Sapsağlam, Ö. \& Ömeroğlu, E. (2015). Okul öncesi öğretmenlerinin eğitim programlarında değerler eğitimine yer verme düzeylerinin belirlenmesi, International Journal of Eurasia Social Sciences, 6(21), 244-264. 
Sarı, E. (2005). Öğretmen adaylarının değer tercihleri: Giresun eğitim fakültesi örneği. Değerler Ĕ̆itimi Dergisi, 3(10), 73-88.

Tarkoçin, S., Berktaş, D. \& Uyanık Balat, G. (2013). Okul öncesi öğretmenlerinin sınıf içi etkinliklerde çocuklarla olan iletişimlerinde kullandıkları değerlerin incelenmesi. Pegem Ĕ̌itim ve Öğretim Dergisi, 3(2), 37-49.

Thompson, M. (2011). Developing moral values in children: Observations from a preschool. IFE PsychologIA, 19(2), 394-411.

Thornber, R.\& Oğuz, E. (2013). Teachers' views on values education: A qualitative study in Sweden and Turkey. International Journal of Educational Research, 59, 49-56.

Thornberg, R. (2008). The lack of professional knowledge in values education. Teaching and Teacher Education: An International Journal of Research and Studies, 24(7), 1791-1798.

Uzun, M. \& Köse, A. (2017). Okul öncesi eğitimde değerler eğitiminin uygulanmasına yönelik öğretmen görüşleri. Bayburt Eğitim Fakültesi Dergisi, 12(23), 305-338.

Ülavere, P. \& Veisson, M. (2017). Values and values education in estonian preschool child care institutions. Journal of Teacher Education for Sustainability, 17(2), 108-124.

Veugelers, W. \& Kat, E. (2003). Moral task for the teacher according to students, parents, and teachers. Educational Research and Evaluation, 9(1), 75-91.

Witherspoon, W. A. (2007). Character education: Determining barriers to implementation. (Unpublished doctoral dissertation). Graduate School of George Fox University, Virginia, USA.

Whitney, I. B. (1986). The status of values education in the middle and junior high school of Tennessee (Unpublished doctoral dissertation). Tennessee State University, United States. Erişim adresi: https://digitalscholarship.tnstate. edu/dissertations/AAI8802627/

Xiaoman, Z. (2006). Moral education and values education in curriculum reform in China. Front. Eduction China, 2, 191-200.

Yalmanc1, S. (2009). Öğretmen adaylarının değer yönelimlerinin çeşitli değişkenler açısından incelenmesi (Yüksek lisans tezi). Zonguldak Karaelmas Üniversitesi Sosyal Bilimler Enstitüsü, Zonguldak.

Yapıcı, A., Kutlu, M. O. \& Bilican, F. I. (2012). Öğretmen adaylarının değer yönelimleri. Elektronik Sosyal Bilimler Dergisi, 11(42), 129-151.

Yazar, T. (2011). Öğretmen adaylarının değerler hakkındaki görüşleri. Pegem Ĕ̆itim ve Öğretim Dergisi, 2(1), 62-68. 
Yazar, T., \& Erkuş, S. (2013). Okul öncesi öğretmenlerinin okul öncesi eğitim programındaki değerler eğitimine ilişkin görüşlerinin değerlendirilmesi. Dicle Üniversitesi Ziya Gökalp Ĕ̈itim Fakültesi Dergisi, 20, 196-211.

Yıldırım, K. (2009). Values education experiences of Turkish class teachers: A phenomonological approach. Eurasian Journal of Educational Research, $35,165-184$.

Yılmaz, E. (2009). Öğretmenlerin değer tercihlerinin bazı değişkenler açısından incelenmesi. Değerler Ĕgitimi Dergisi, 7 (17), 109-128.

Yılmaz, M. \& Yılmaz, Ö. F. (2017). Sınıf ve okul öncesi öğretmenlerinin değer öğretimine ilişkin görüşleri. Bartın Üniversitesi Eğitim Fakültesi Dergisi, 6(2), 737-748.

Yuvac1, Z. (2013). Okulöncesi değer eğitimi uygulayan okullardan seçilen değerlerin ve etkinliklerin incelenmesi (Yüksek lisans tezi). Dumlupınar Üniversitesi Eğitim Bilimleri Enstitüsü, Kütahya

Zavalsız, Y. S. (2014). Üniversite öğrencilerinin değer algısı (Karabük Üniversitesi örneği). Turkish Studies, 9(2), 1739-1762. 


\title{
Pre-school Teacher Candidates' Views on Values Education
}

\author{
Hatice Kübra AKITÜRK, M.D. Student, \\ Bursa Uludag University, Institute of Educational Sciences. \\ E-mail: laledansi@gmail.com.
}

ORGID: 0000-0001-6115-3543

Pınar BAĞÇELİ KAHRAMAN, Corresponding Author, Assistant Professor.

Bursa Uludag University, Faculty of Education.

E-mail: pinarbag@uludag.edu.tr.

ORGID: 0000-0002-0551-7741

\section{Introduction}

Although values, beliefs and attitudes seem concentric, values are more inclusive than beliefs and attitudes (Demircioğlu and Tokdemir, 2008). Value means the importance or superiority ascribed to an object, being or activity by individuals and society (Aydin, 2010). The purpose of Values Education is to raise individuals as people who has responsible character with wise and have moral values (Altan, 2011; Kulaksızoğlu and Dilmaç 2000). Before starting school it is the family's responsibility to teach values, after the child starts school this responsibility belongs to the teacher (Erikli, 2016). Therefore, the task of the school is to teach the children the values that is put in the education program and support their moral development within the frame of certain rules (Akbaş, 2008). Preschool education plays an important role in teaching values (Aydin, 2010). In preschool period supporting the development of the children directing their behaviours and attitudes, is actualised by teaching values (Öztürk Samur, 2011). Therefore in this period teaching the values that lay the way open for the 
personal and social life of the children is considered as a start (Neslitürk, 2013). Within the scope of the Preschool Education program the values put into practice are; respect, love, mutualisation and cooperation, kindness and tolerance, peace, self confidence, responsibility, solidarity and sharing (MEB, 2013).

In order to provide values education at schools, it is very important for teachers, who contribute to the process significantly, to examine all aspects in this process (Kolaç and Karadağ 2011; Kurtulmuş, 2014). For this purpose the teachers must know the children in the classroom very well and observe which values they can acquire. For a teacher to teach the child a value, he or she must internalize this value first (Kasapoğlu, 2013). Studies, that aim to reveal the views of teacher candidates toward values and values education were carried out in that regard (Aydın and Sulak, 2015; Dilmaç, Bozgeyikli and Çıkı1l, 2008; Huşu and Tirri, 2007; Kurtdede and Fidan, 2009; Oğuz, 2012; Yalmanc1, 2009; Yazar, 2011). In Başal, Çelebi and Malak's (2016) study, in which they searched whether or not there is a relationship between preschool teacher candidates' focus of control and human values, they determined that there was not a significant relationship between focus of control and human values. In the study of Karasu, Avc1 and İbret (2016), the determination of teacher candidates' views towards patriotism was aimed. They found that in raising patriot individuals, the role of the preschool teachers and gaining this value was related in case this value was hold by preschool teachers. On the other hand, different from other researches, this research aimed at examining only the views of preschool teacher candidates on values education.

In accordance with this purpose we tried to determine the views of preschool teacher candidates towards values education, the values that they consider important to apply at schools and whether they see themselves adequate or not regarding these values.

\section{Method}

\section{Research Model}

In this research which aims to determine the views of preschool teacher candidates, scanning model, which is a quantitative research model was used and criterion sampling was utilized for the sample of the research. 


\section{Sample}

Attending Special Teaching Methods 1 and 2 courses was determined as the criterion for the research. These courses are based on the teachers' knowing the preschool education program and planning activities depending on the learning objectives that take place in the program. In the preschool education program the values respect, love, mutualisation and cooperation, kindness and tolerance, peace, self confidence, responsibility, solidarity and sharing are especially emphasized. These values are also included in learning objectives. It is thought that teacher candidates can give more accurate replies to the questions about values and its education after attending these courses. Therefore especially the teacher candidates, who attended Special Teaching Methods 1 and 2 courses, were involved in the sample. The sample of the research consists of 116 students who attended Education Faculty Preschool Department in 2018-2019 education year. 6 of the students participated in the study are male and 100 of them are female. 34 of the participants were from grade 3 and 82 of them were from grade 4. Considering the age distribution of the participants, it is seen that 29 people were between 20 and 21; 49 people were between 22 and 23; and 38 people were 23 and beyond. Among 116 teacher candidates who is participated 6 of them received values education and 110 of them did not take the courses. 4 out of the 6 candidates who took courses for the values education considered the training sufficient, while 2 of them did not find the training satisfactory.

\section{Data Collection and Analysis}

For gathering the data of the research that appropriate for the purposes of the research, values education oriented interview form was used. In the first part of the form information regarding the variables such as gender, age and grade were asked. In the second part eight open ended questions to determine the views of candidates towards values education were added.

Within the scope of this research, which was planned for the determination of preschool teacher candidates' views towards values education, the data obtained from the interview form was analysed through frequency analysis and it was presented in percentage and frequency tables.

Findings, Conclusion and Suggestions

In this research, it was found that most of the teacher candidates, who participated in the research, defined values education as transferring universal values 
and stated that in preschool period values education was important since it is the most important age range of the personal development. Most of the teacher candidates participated in the research defined values education as transferring the universal values; this parallels the values education directives of The Ministry of National Education; "Fulfilling the duty of transferring our values to next generations, thus providing an individual and collective protection from the increasing risks and threats". In addition, it can be stated that starting values education at an early age with parents and teachers being as role models are important for the child internalizing the values. In this sense it can be stated that preschool teacher candidates related the importance of values education with the importance of preschool education.

Preschool teacher candidates stated that the easiest values to be taught in the preschool period were love, respect and help; on the other hand, it was difficult to teach empathy, respect and honesty values. It was determined that teacher candidates, who participated in the research, also stated that values education can be provided by creative drama, games and Turkish course activities. Kozikoğlu (2018), concluded that teachers perform drama, play and Turkish activities, art activities and visual and auditory activities in value education. Values education can be provided by different activities and skills acquisition in the Preschool Education Program. In addition teacher candidates' considering respect value both as easy and difficult to teach, suggests that they do not have much information regarding the issue of values education.

As a result of this research it was revealed that teacher candidates give priority to respect, love, tolerance and honesty values in their lives. Also preschool teacher candidates stated that they behave according to the values need to be taught in preschool period. Researches deal with preschool teachers reveal that when the values education was mentioned, values of respect, love, honesty and cooperation has come to the minds of preschool teachers (Kozikoğlu, 2018; Ogelman ve Sarıkaya, 2015; Sapsağlam ve Ömeroğlu, 2015; Tarkoçin, Berktaş, Uyanık Balat 2013; Uzun ve Köse, 2017; Yazar ve Erkuş, 2013).

In preschool period the child favours the values observed in his or her teacher and learns these values by turning them into behaviours. Therefore, teachers must have these values and be a role model. However it is seen that preschool teacher candidates include some skills and concepts in the values. Most of the teacher candidates participated in this research had not attended a lesson regarding values and its education. In this sense it is thought that applied courses 
regarding values education must be provided in universities in terms of teacher candidates observing how they can teach values. Moreover, it is recommended to conduct further experimental studies, that aims to examine whether the courses teacher candidates take having the potential to make a difference or not in their knowledge and opinions.

Preschool teacher candidates' stating that they behave according to the values education is an important result. Nonetheless, it is thought that determining whether teacher candidates behave according to the values education or not, is also important especially in the application dimension of Teaching Practice courses. Thus, turning values and opinions into behaviours will be attained. 